\title{
Коллекция шаманских бубнов в фондах Национального музея Тувы
}

\section{Ульяна П. Бичелдей}

Тувинский институт гуманитарных и прикладных социально-экономических исследований при Правительстве Республики Тыва, Российская Федерация,

Анай-Хаак М. Допай, Саида Л. Бырыннай

Национальный музей им. Алдан-Маадыр Республики Тыва, Российская Федерация

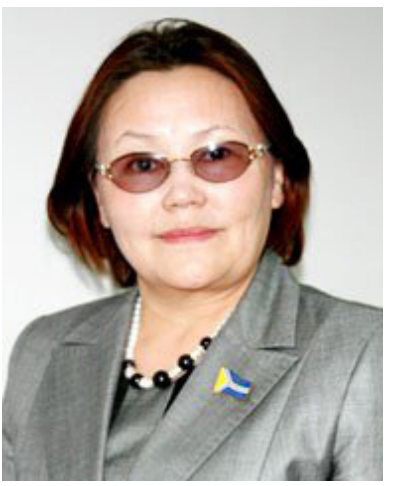

В статье представлены материалы шаманской коллекции, в частности шаманских бубнов, из фондов Нациионального музея Республики Тыва. Предметов шаманского культа насчитывается здесь более 500 единии, бубнов - 14. Имеются также и колотушки, неизменные спутники шаманского бубна. Все они принадлежали тувинским шаманам разных лет. Рассматриваются вопросы коллекционирования, комплектации, хранения бубнов. Источниковой базой стали сведения книги поступления, инвентарной книги. Статья сопровождается фотографиями бубнов. Предметы размещены в постоянной экспозиции музея.

Сбором шаманских бубнов в музее начали заниматься с середины ХХ в. Первый поступил, предположительно, в 1951 г. Подробно описаны имеющиеся сведения по ряду бубнов: история поступления, датировки, изготовитель, материал, инвентарный номер, сохранность и $\mathrm{np}$.

Авторами статьи выявлено, что бубны различаются по способу изготовления и по

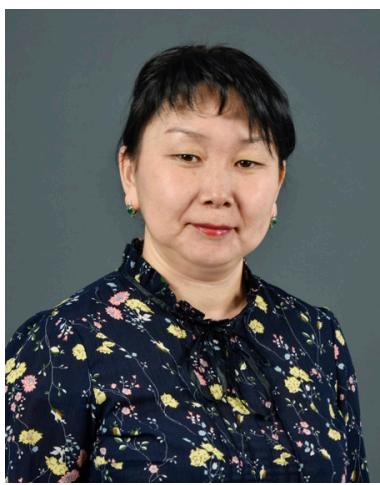
методике украшения разной специальной атрибутикой. Подтверждены предположения исследователей о различиях между бубнами в зависимости от места их происхождения - западная и восточная Тува. Главные различия в использовании шкур разных животных, составе деревянного остова бубна, в символике рукояти, в количестве резонаторов на ободе, особенностях дополнительных атрибутов во внутренней части бубна.

Сам состав коллекции, ее характеристики, позволяют заключить, что она является одной из наиболее укомплектованных, представляющей практически всю культовую атрибутику тувинских шаманов. Коллекция продолжает дополняться теперь и атрибутикой неошаманов.

Ключевые слова: Национальный музей Тувы; шаманская коллекция; бубен; шаманизм; шаманский бубен; тувинский шаманизм
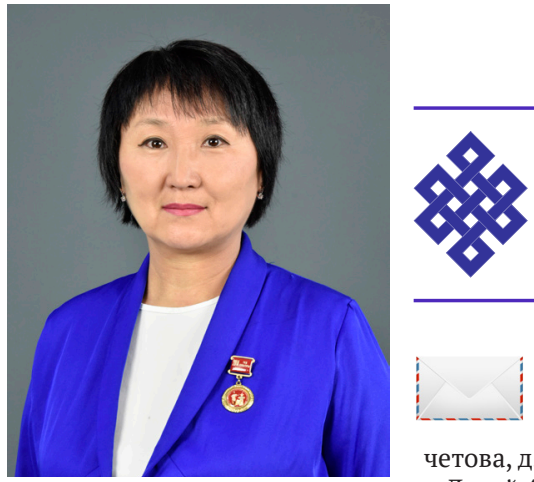

\section{Для цитирования:}

Бичелдей У. П., Допай А.-Х. М., Бырыннай С. Л. Коллекция шаманских бубнов в фондах Национального музея Тувы [Электронный ресурс] // Новые исследования Тувы. 2019, № 2. URL: https://nit.tuva.asia/nit/article/view/853 (дата обращения: дд.мм.гг.). DOI: 10.25178/nit.2019.2.13

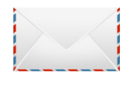

Бичелдей Ульяна Павловна - доктор религиоведения (Ph.D), руководитель группы религиоведения Тувинского института гуманитарных и прикладных социально-экономических исследований при Правительстве Республики Тыва. Адрес: 667000, Россия, г. Кызыл, ул. Кочетова, д. 4. Тел.: +7 (913) 341-28-33. Эл. адрес: opei-ool@yandex.ru ORCID ID: 0000-0001-5588-9167

Допай Анай-Хаак Михаиловна - хранитель I категории отдела учета и хранения фондов (религиознокультовые предметы) Национального музея им. Алдан-Маадыр Республики Тыва. Адрес: 667000, Россия, г. Кызыл, ул. Титова, д. 30. Тел.: +7 923-549-98-46. Эл. адрес: dopay2017@mail.ru ORCID ID: 0000-0002-1725-4600

Бырыннай Саида Лопсановна - хранитель I категории отдела учета и хранения фондов (предметы декоративно-прикладного искусства) Национального музея им. Алдан-Маадыр Республики Тыва. Адрес: 667000, Россия, г. Кызыл, ул. Титова, д. 30. Тел.: +7 (923) 380-84-77. Эл. адрес: saidabyrynnaj-68@mail.ru ORCID ID: 0000-0001-9653-8654

Bicheldey Ulyana Pavlovna, Doctor of religious studies (Ph.D), Head, Religious studies unit, Tuvan Institute for the Humanities and Applied Social and Economic Studies. Postal address: 4 Kochetov St., 667000 Kyzyl, Russian Federation. Tel. +7 (394-22) 2-39-36. E-mail: opei-ool@yandex.ru

Dopay Anai-Khaak Mikhailovna, Category I Custodian, Department of Collections Storage and Control (religious and ritual objects), AldanMaadyr National Museum of the Republic of Tuva. Postal address: 30 Titov St., 667000 Kyzyl, Russian Federation. Tel.: +7 (923) 549-98-46. E-mail: dopay2017@mail.ru

Byrynnay Saida Lopsanovna, Category I Custodian, Department of Collections Storage and Control (decorative and applied arts), Aldan-Maadyr National Museum of the Republic of Tuva. Postal address: 30 Titov St., 667000 Kyzyl, Russian Federation. Tel.: +7 (923) 380-84-77. E-mail: saidabyrynnaj-68@mail.ru 


\title{
A collection of shaman tambourines from the National Museum of the Republic of Tuva
}

\author{
Ulyana P. Bicheldey \\ Tuvan Institute for Humanities and Applied Socioeconomic Studies, Russian Federation, \\ Anai-Khaak M. Dopay, Saida L. Byrynnai \\ Aldan-Maadyr National Museum, Republic of Tuva, Russian Federation
}

\begin{abstract}
This article is an attempt to bring together data relating to the shaman's tambourine and its features, based on the materials of the shaman collection in the National Museum of the Republic of Tuva. The collection holds more than 500 objects of shamanic ritual, including 14 tambourines and a number of beaters, which always come together with the former. Each of the tambourines once was property of a shaman. The article also looks at the issues of collecting, acquiring and preserving tambourines, relying on the acquisition and storage books. It is also accompanied by photos of the tambourines in the museum's permanent collection.

The museum's tambourine collection began in the middle of the 20th century, with the earliest piece arriving, allegedly, in 1951. The article provides detailed metadata on a number of tambourines, including their provenance, dating, maker, material, current state and inventory number, among other parameters.

The authors have discovered that tambourines differ by the way they are made and decorated with various accoutrements. It has also been proved that tambourines made in western Tuva differ from their counterparts in the east of the region, the major difference lying in the use of skins of various animals, composition of the tambourine's wooden frame, the symbolism of the handle, the number of cavities in the rim, and the use of additional elements inside the tambourine.

The composition and structure of the collection make it one of the best among its competitors, since almost all of the ritual attributes of Tuva shamans are features on it. At present, the collection is being expanded to include objects of used by neoshamans.
\end{abstract}

Keywords: National Museum of the Republic of Tyva; shaman collection; tambourine; Shamanism; shaman's tambourine; Shamanism in Tuva

For citation:

Bicheldey U. P., Dopay A.-Kh. M. and Byrynnai S. L. A collection of shaman tambourines from the National Museum of the Republic of Tuva. The New Research of Tuva. 2019, № 2 [online] Available at: https://nit.tuva.asia/nit/article/view/853 (access date ...). DOI: 10.25178/nit.2019.2.13

\section{Введение}

Одним из феноменом духовного и материального наследия тувинского народа является шаманизм, изучение которого на сегодня является актуальным как в общих вопросах (религиозные воззрения, социокультурные функции и пр.) (Потанин, 1883; Элиаде, 2015; Федоров, 2005; Потапов, 1969), так и в частных. К числу последних можно отнести исследования предметов шаманского культа, самым узнаваемым из которых является бубен. Он играл первостепенную роль в шаманских церемониях и является важной ритуальной принадлежностью шамана. У тувинских шаманов, по утверждению М. Б. Кенин-Лопсана, бубен служил одновременно «конем» и «щитом» во время его путешествий по разным мирам (Кенин-Лопсан, 1987: 51-55). Также шаманский бубен имели право носить только «сильные» шаманы (Кенин-Лопсан, 2009: 137). Вместе с возрастанием жреческого дара или особой силы, шаман, по внушению духа-предка, начинал просьбу у своих сородичей, дать ему колотушку (орба) и бубен (дүңгүр). У тувинских шаманов бытовала традиция, имеющая отношение к бубну и шаманскому жезлу (даяк), который, на наш взгляд, доказывает неразрывную связь бубна и жезла. Если шаман получал даяк осенью, то бубен ему делали либо зимой в середине февраля, либо весной к середине мая (Вайнштейн, 1961: 177).

Национальный музей им. Алдан-Маадыр Республики Тыва имеет значительную коллекцию предметов шаманского культа - более 500 единиц хранения. При этом это одна из самых ценных и востребованных этнографических коллекций тувинского музея. Ее состав в полной мере отражает культовую атрибутику тувинского шаманизма, начиная с одежды шамана (тон - плащ, бөрт - головной убор), основных его атрибутов (даяк - жезл, күзүнгү - зеркало, хомус и т. д.), и заканчивая разновидностями многочисленных духов-помощников шамана (ээрен), а также семейными охранителями-оберегами (эмегелчин). 
Шаманских бубнов (дүңгүр) в музее насчитывается 14 экз. Все они принадлежали тувинским шаманам разных периодов. Имеются также и колотушки (орба), которые являются неизменными спутниками шаманского бубна. Тувинские шаманы использовали орба в двух целях: 1) для ударов о бубен, чтобы извлечь из него звук; 2) для проведения гадания с целью предсказывания судьбы человека (КенинЛопсан, 2009: 137-144). Этот обряд шаманы называли төлге каары - гадание при помощи шаманской колотушки, которым, обычно, завершалось шаманское действо. Орба заслуживает отдельного внимания исследователей, поскольку имеет собственную, не менее интересную символику.

Настоящая статья представляет собой попытку свести воедино данные, касающиеся одного из главных атрибутов шаманской мистерии - бубна и его особенностей, опираясь на материалы шаманской коллекции фондов Национального музея Республики Тыва.

При подготовке данной статьи авторы, прежде всего, опирались на исследования известного этнографа, доктора исторических наук, ветерана Национального музея Республики Тыва М. Б. Кенин-Лопсана, который всю свою музееведческую деятельность занимался систематическим описанием и анализом тувинского шаманства (Кенин-Лопсан, 1987, 2009). Особую ценность для исследователей шаманизма представляют его выводы, сделанные в отношении исторических и культурных аспектов тувинского шаманизма. Работая в Национальном музее Республики Тыва с 1966 г. по настоящее время, он много времени уделил также комплектации шаманских предметов.

Необходимо также отметить большой вклад в работу по научной инвентаризации и атрибуции шаманской коллекции, в том числе и бубнов, внесенный сотрудниками музея - Л. М. Салчак, У. Б. Нурзат и А. В. Дамба. Научные изыскания и фактический музейный материал, собранный М. Б. Кенин-Лопсаном и указанными научными сотрудниками музея, легли в основу этой работы.

\section{Из истории изучения шаманских бубнов}

Первые материалы о тувинском шаманизме содержатся в работе востоковеда П. А. Чихачева, издавшего в 1845 г. фундаментальный труд «Путешествие в восточный Алтай», в котором он утверждал, что тувинское шаманство идентично с алтайским (Chikhachev, 1845; Чихачев, 1974: 172).

Атрибутам тувинских шаманов уделил внимание Г. Н. Потанин в «Очерках в Северо-Западной Монголии» (Потанин, 1883: 7-10). О тувинском шаманском бубне и колотушке оставил свои наблюдения известный хакасский исследователь Н. Ф. Катанов, посетивший Урянхайский край (Туву) вначале ХХ в. (Катанов, 1893: 114).

Наиболее глубокое исследование тувинского шаманизма осуществил М. Б. Кенин-Лопсан. В 1987 г. на основе его кандидатской диссертации впервые была издана монографическая работа, посвященная тувинскому шаманизму (Кенин-Лопсан, 1987).

М. Б. Кенин-Лопсан выделил два этапа как в развитии, так и научном изучении шаманизма Тувы. Первый этап изучения тувинского шаманизма, по его мнению, определяется работами Е. К. Яковлева (Яковлев, 1900: 87-122), Ф. Я. Кона (Кон, 1934), Г. Е. Грумма-Гржимайло (Грумм-Гржимайло, 1926: 119-183). Второй этап изучения тувинского шаманства и его атрибутики обозначился именами таких известных советских ученых, как С. И. Вайнштейн (Вайнштейн, 1961), В. П. Дьяконова (Дьяконова, 1977), Л. П. Потапов (Потапов, 1960), Н. А. Алексеев (Алексеев, 1980).

Свои работы тувинскому шаманизму посвятили и зарубежные исследователи. Венгерский ученый В. Диосеги изучал как внутриэтнические различия, так и межэтническую аналогию тувинского шаманизма (Dioszegi, 1962). Шаманизм у тувинцев сумона Сэнгэл Баян-Ульгийского аймака Монголии исследовала немецкий монголовед Э. Таубе (Taube, 1981: 33).

\section{Описание коллекции бубнов}

Коллекция шаманских бубнов с колотушками, которая хранится сегодня в Национальном музее Тувы, как сама по себе, так и в части истории своего формирования - представляет собой интереснейшую источниковую базу для исследования особенностей этих предметов шаманского культа.

Сбором шаманских бубнов в музее начали заниматься с середины XX в.

14 шаманских бубнов с колотушками зафиксированы в книгах поступлений (КП) под №№ 1, 3, 9, 17, 19, 20 и 21 основного фонда.

Представим некоторые из них. 
Первый шаманский бубен в фонды музея поступил, предположительно, в 1951 г. (фото 1).

Он представляет для музея большую ценность, потому что был доставлен из Тоджи известным ученымэтнографом С. И. Вайнштейном во время его научной экспедиции. Но, к сожалению, нет достоверной информации, кому из тоджинских шаманов он принадлежал.

Бубен сделан из кожи крупного рогатого скота, стянутой у основания обечайки (өзээ) или обода (куржаг). Обод представляет собой основу бубна, и состоит из деревянного кольца, на который натягивается шелковой нитью кожа. Вокруг обода бубна имеются 18 резонаторов (хөөн дынзыдыкчызы). Рукоятка бубна украшена геометрическим орнаментом. На него подвешены конусообразные латунные подвески. Инвентарный № 1130, размеры - 73×18 см., акт приемки отсутствует.

Следующий бубен (фото 2) изготовлен из белой, неокрашенной кожи, вероятнее всего, домашнего козла, натянутой на деревянный обод. Рукоять округлая, с барельефными фигурами змеи и шамана. На внутренней части обода имеются две скобы, к которым прикреплены железные свирельки. К рукояти бубна привязаны шелковые тэнгрианского синего цвета хадаки. На бубне имеется большой ритуальный разрез. Инвентарный № 1537; размеры - 57×17 см., год поступления, предположительно, 1950-е гг., акт приемки отсутствует.

В 1963 г. С. И. Вайнштейн в очередной раз побывал с экспедицией на озере Тере-Холь, где он проводил раскопки на развалинах уйгурской крепости Пор-Бажын. В это время ему удалось встретиться с местным знаменитым шаманом Сояном Шончуром и получить для музея его бубен (фото 3).

Бубен шамана Шончура отличается тем, что он изготовлен из кожи марала и на лицевой части его кожаного покрытия нарисован своеобразный рисунок, выполненный оранжевой охрой. Аналогов подобного бубна в фондах музея не имеется. Рисунок представляет собой схематическое изображение верхнего и нижнего миров, напоминает древние наскальные рисунки, относящиеся к самому началу нашей эры. В верхнем мире изображены девятиярусное небо - Тос Дээр, в нижнем - марал и 2 хвойных дерева, вероятнее всего, красные лиственницы. Инвентарный № 112, размеры - 70×17 см.

Следующий шаманский бубен был доставлен из западной Тувы. Он сделан из кожи домашнего козла, натянутой на деревянный обод. На верхней части рукояти - резные изображения духа-покровителя и духа-предка шамана. Инвентарный номер отсутствует, размеры - 68×16 см., акт приемки от 1960 г.

Следующий шаманский бубен (фото 4) с колотушкой принадлежит шаману С. С. Дугеру из с. Кунгуртуг Тере-Хольского кожууна. Бубен изготовлен из кожи домашнего козла, натянутой на деревянный обод (куржаг). Он отличается от других бубнов 9 резонаторами. Необходимо подчеркнуть, что число резонаторов на бубне наделяется магическим смыслом с многочисленными толкованиями. Рукоять бубна состоит из крестообразных деревянных палок с чалама и двумя жгутами - символами шаманских змей. Инвентарный № 5105, размеры - 69×16 см., акт приемки от 1970 г.

В 1983 г. у Лазо Монгуша, уроженца села Хорум-Даг Дзун-Хемчикского кожууна, музеем был закуплен шаманский бубен с колотушкой (фото 5). Бубен сделан из кожи домашнего козла с дополнительной отделкой из овечьей шкуры, что отличает его от других бубнов, в которых часто используется шкура только одного животного. Остов бубна состоит из двух алюминиевых обручей. На рукояти бубна прикреплено изображение фигуры шамана, вырезанной из картонной бумаги. По краям бубна пришиты кисточки с вдетыми бусинками красного цвета и игральными костями, также имеются металлические колокольчики. Инвентарный № 8338, размеры $-67 \times 14,5$ см., акт приемки от 01.08.1983 г.

Следующие поступления в шаманское собрание музея отмечены уже началом XXI века.

В 2003 г. фонды музея пополнились сразу двумя шаманскими культовыми коллекциями, которые были сданы родственниками умерших шаманов.

Одна из коллекций принадлежала целителю-костоправу О. П. Тойдуку, уроженцу села Кызыл-Даг ЧааХольского кожууна.

На деревянный обод бубна жильными нитями натянута шкура домашней козы (фото 6). Рукоять состоит из двух крестообразных деревянных жердочек с колокольчиками и чалама (ленточки). По краю околыша бубна имеются 12 выступов, символизирующих 12 годов летоисчисления. От других шаманских коллекций музея данный бубен отличается своим внушительным размером и сильными резонаторами. На бубне ритуальный разрез отсутствует. Инвентарный № 10718/1, размеры - 74×10 см., акт приемки от 18.08.2003 г.

Следующий бубен О.П. Тойдука (фото 7) состоит из деревянной обечайки с 9-ю резонаторами. Обтянут кожей домашнего козла, предположительно белого цвета, на некоторых местах обечайки сохранились шерстинки белой окраски. Кожа у основания обечайки стянута толстой шелковой нитью. 


\section{НОВЫЕ ИССЛЕДОВАНИЯ ТУВЫ}

www.nit.tuva.asia
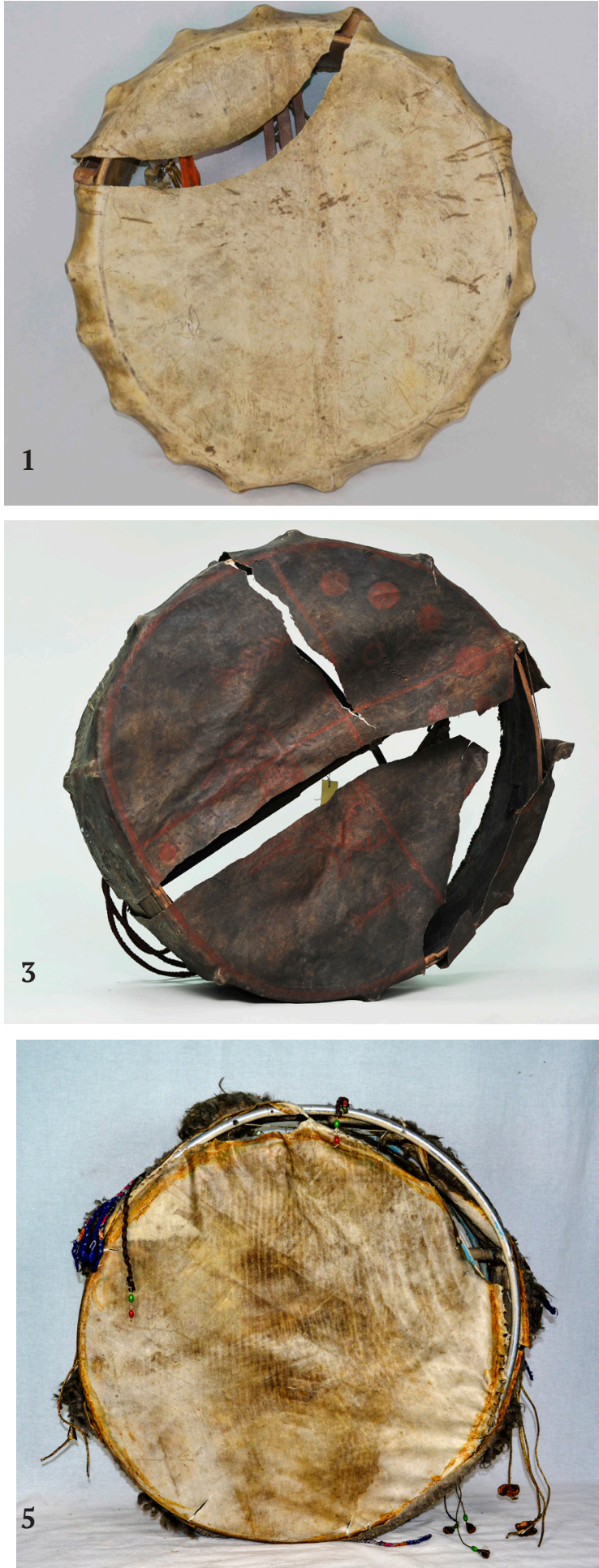

Фото 1-6: 1 - Бубен, доставленный С. И. Вайнштейном из Тоджи, прим. в 1951 г. Фото А. Д. Куулар, 2019 г.;

2 - Бубен неизвестного шамана, поступил прим. в 1950-е гг. Фото А. Д. Куулар, 2019 г.; 3 - Бубен Соян Шончура, поступил 8 1963 г. Фото С. М. Еловикова, 2015 г.; 4 - Бубен С. С. Дугера, доставленный из западных районов в 1970 г. Фото А. Д. Куулар,

2019 г.; 5 - Бубен шамана Л. Д. Монгуш, поступил в 1983 г. Фото А. Д. Куулар, 2019 г.; 6 - Бубен 1 О. Тойдука. Фото А. Д. Куулар, 2019 г.

Photo 1-6: 1. The tambourine brought by S. I. Vainshtein from Toja, acq. 1951. Photo by A. D. Kuular, 2019; 2. The tambourine of an unknown shaman, acq. c. 1950s. Photo by A. D. Kuular, 2019;

3. Soyan Shonchur's tambourine, aca. 1963. Photo by S. M. Elovikov, 2015;

4. S. S. Duger's tambourine, brought from the western rayons of Tuva in 1970. Photo by A. D. Kuular, 2019; 5. The tambourine of shaman L.D. Mongush, acq. 1983. Photo by A. D. Kuular, 2019; 6. БO. Toyduk's tambourine 1. Photo by A. D. Kuular, 2019. 


\section{НОВЫЕ ИССЛЕДОВАНИЯ ТУВЫ}

\section{THE NEW RESEARCH OF TUVA}

www.nit.tuva.asia

№2

Novye issledovaniia Tuvy
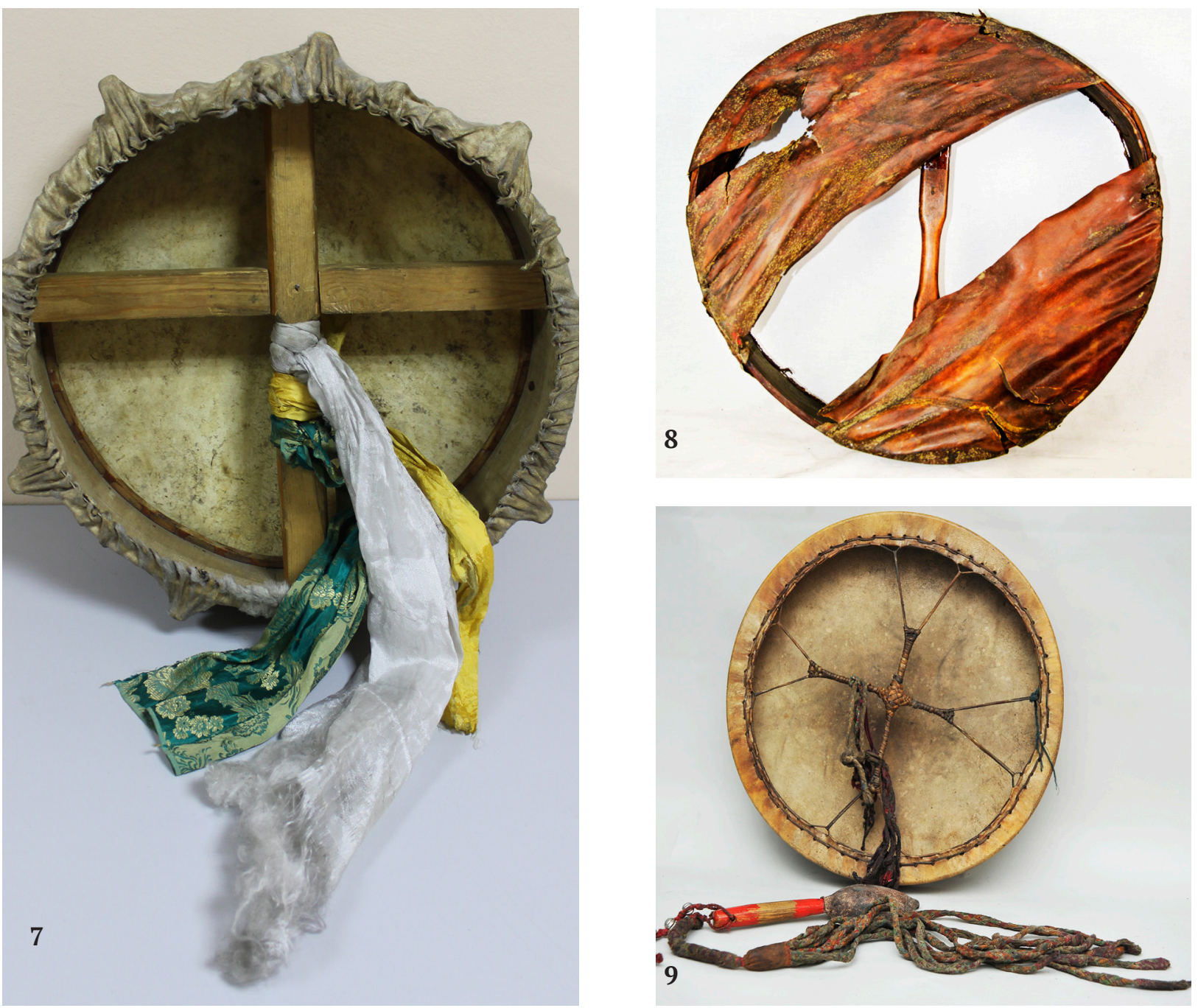

Фото 7-9: 7 - Бубен 2 О. Тойдука. Фото А. С. Хертек, 2017 г.; 8 - Бубен, вывезенный из Тувы в 1929 г. О. Мэнхен-Хельфеном. Фото А. Д. Куулар, 2019 г.; 9 - Бубен с колотушкой А.-Ч. Ш. Оюн. Фото С. М. Еловикова, 2016 г. Photo 7-9: 7. O. Toyduk's tambourine 2. Photo by A. S. Khertek, 2017;

8. The tambourine which Otto Männchen-Helfen brought from Tuva in 1929. Photo by A. D. Kuular, 2019; 9. A-Ch. Sh. Oyun's tambourine and beater. Photo by S.M. Elovikov, 2016.

Резонаторы бубна прикреплены к ободу поперечно через равные расстояния, каждый резонатор имеет три выступа. Лицевая часть бубна без рисунков, на ней появились трещинки, возможно, от того, что бубен не используется уже длительное время. Также во внутренней части бубна, имеются 2 деревянные крестообразные перекладины, вставленные в пазы друг друга, посередине их соединения забит гвоздик. Одна из перекладин (вертикальная) служит рукоятью. К ней привязаны 3 ленты (одна под другой):

- шелковый кадак белого цвета с бахромой на концах;

- отрез прямоугольного шелкового лоскута с вышивкой из блестящих желтых ниток цветочного узора, сделанной на швейной машинке;

- отрез шелкового двустороннего прямоугольного лоскута ткани, с вышитым контрастными нитками цветочным узором (с одной стороны - зеленый фон с вышивкой желтыми нитками, с другой стороны желтый фон с зеленой вышивкой).

На расстоянии 13,5 см. от верха второй поперечной (горизонтальной) перекладины, являющейся нижней частью, прикреплена рукоять бубна. На бубне ритуальный разрез отсутствует. Инвентарный № $10718 / 3$, размеры $-45 \times 12,5$ см.

Среди 10 предметов, принадлежащих умершему шаману М.С. Куулару, также имеются бубен с колотушкой. Бубен М. С. Куулара обтянут шкурой домашнего козла и закреплен к нижнему краю обечайки стежками. Внутренняя часть представлена крестообразными деревянными перекладинами разной 
НОВЫЕ ИССЛЕДОВАНИЯ ТУВЫ

www.nit.tuva.asia

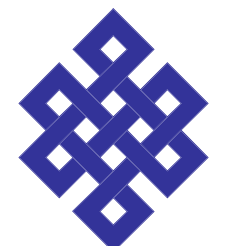

ширины. На узкой перекладине привязаны разноцветные чалама, медный колокольчик, вероятно, подаренные духу бубна, с целью его умилостивления.

На верхней части широкой перекладины вырезан некий лик, символизирующий камлающего шамана, явно находящегося в разъяренном состоянии. Инвентарный № 10693 , размер - 58,8×13,2 см.; акт приемки от 26.03.2003 г.

Следующий бубен имеет интересную историю. В 1929 г. он был подарен известному этнографу и писателю О. Мэнхен-Хельфену в знак благодарности за его искренний интерес к культуре народа молодого тувинского государства (фото 8). Завершив свое путешествие по Туве, путешественник взял этот бубен в Австрию. Когда семья МэнхенаХельфена эмигрировала из Европы, бубен вместе с ними оказался в США (Оюн, 2006: Электр. ресурс). Спустя почти 80 лет он снова оказался в Туве. Его привезли тувинские музыканты этноансамбля «Алаш». Об этом бубне упоминает Анна - вдова О. МэнхенХельфена в предисловии английского перевода книги «Reise ins Asiatische Tuwa» («Путешествие в азиатскую Туву»), изданной в

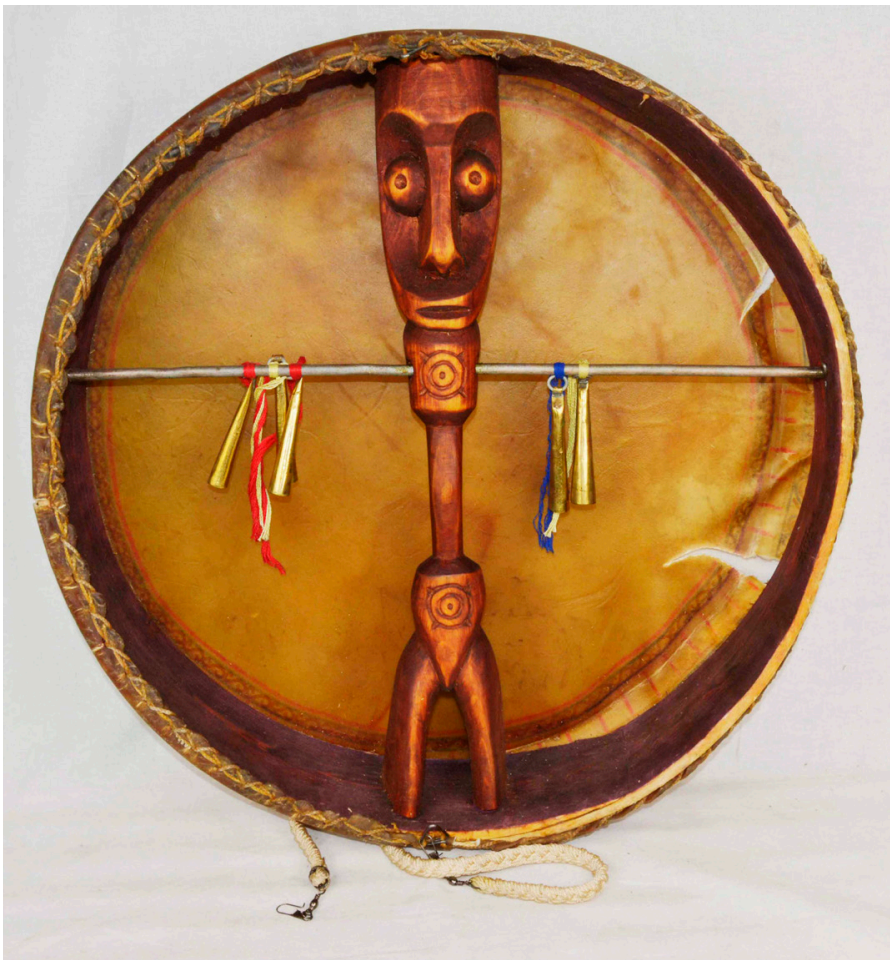

Фото 10. Бубен М. Б. Кенин-Лопсана. Фото А. Д. Куулар, 2019 г. Photo 10. M. B. Kenin-Lopsan's tambourine. Photo by A. D. Kuular, 2019. 1931 г. в Берлине по итогам его путешествия в ТНР. К сожалению, информация о том, кому из шаманов принадлежал этот бубен, не сохранилась.

На обод этого бубна жильными нитями натянута шкура животного. Лицевая часть бубна имеет два ритуальных разреза. На деревянной рукояти вырезаны фигуры змейки и человека. Инвентарный № 11306, размеры - 63×15 см., акт приемки от 03.03.2009 г.

В 2011 г. в фонды музея поступил шаманский бубен с колотушкой, принадлежащие молодому шаману Б. А. Сояну. По словам Буяна Адавасовича, бубен был изготовлен Константином Ажыы, мастером шаманских предметов. Бубен из неокрашенной шкуры, с девятью выступами по краям. Рукоять деревянная, резная. К ней привязаны чалама, ээрен в виде духа стихии, пять когтей медведя, клыки волка, ракушки, колокольчики и бусы. Особенностью данного бубна является наличие в нем бронзовой буддийской ваджры. Инвентарный № 11384, размеры 52×10 см., акт приемки от 13.05.2011 г.

Наиболее многочисленную коллекцию в количестве 135 единиц составляют шаманские атрибуты известной в Туве, России и европейских странах шаманки Ай-Чурек Оюн. Они поступили в фонды тувинского музея после ее смерти, в 2016 г.

На деревянном остове бубна (фото 9) кожаными нитями (сиир) гладко перетянута шкура животного. Рукоять бубна сделана из сплетенных кожанных веревок (баг) с разноцветными жгутами - символами змей. Инвентарный № 12056/1, размеры: 48×6 см., акт приемки от 23.10.2017 г.

В фондах Национального музея имеются два бубна, принадлежащие М. Б. Кенин-Лопсану. Помимо того, что он является видным ученым этнографом, он также известен как практикующий шаман, перенявший свой дар по наследству от матери. Следует отметить, что, возможно, второй бубен не принадлежал М. Б. Кенин-Лопсану. Его дочь, А. М. Кенин-Лопсан при сдаче предметов указала, что первый бубен принадлежит ее отцу и ничего не сказала про второй.

У первого бубна шамана М. Кенин-Лопсана (фото 10) остов состоит из деревянных планок круглой формы, на которую натянута кожа. По краям остова нанесен S-образный узор, а по бокам с четырех сторон имеются рисунки в виде кругов. Рукоять бубна состоит из поперечной алюминиевой трубки и вырезанной из дерева фигуры человека, укрепленной горизонтально. Поперек рукояти прикреплены 5 железных свирелей и жгутики, из разноцветных нитей. Инвентарный № 11972/1, размеры - 56×12 см. 
Второй бубен изготовлен из кожи, по внешним краям выступают девять наростов, символизирующих 9 небес. Рукоять этого бубна также, как и бубен шаманки А.-Ч. Оюн, сделана из кожаных ремешков, соединенных сложным плетением (кабдыn). Инвентарный №11972/1, размеры $-51 \times 9$ см., акт приемки датируется 10.04.2017 г.

\section{Особенности бубнов тувинских шаманов}

Л.П. Потапов при классификации бубнов тувинских шаманов по форме их рукоятки, ссылаясь на Г. Н. Потанина (Потанин, 1883: 41), относил их к алтае-саянскому типу, имеющему две перекладины с внутренней стороны: вертикальную и горизонтальную (Потанин, 1883: 41). Также, бубны тувинских шаманов он подразделил на западные и восточные (Потапов, 1969: 351).

Это же отметила и Е. Д. Прокофьева. Она писала: «особенно отличались бубны восточных и западных тувинцев по устройству рукоятки. У восточных тувинцев рукоять бубна представляла собой плоскую, обязательно березовую пластину, украшенную прорезями и орнаментом и выточенную в средней части (для держания рукой). На верхнем конце рукояти иногда вырезали изображения шамана; ниже прикрепляли скобу с длинными лентами - чалама, из тряпок» (Прокофьева, 1961: 455).

Обследование имеющихся в распоряжении музея бубнов показало нам, что они действительно имеют различия и эти различия позволяют их разделять на «западные» и «восточные». Основываясь на сведениях Л. П. Потапова и Е. Д. Прокофьевой, эти различия мы увидели по оформлению рукоятей шаманских бубнов и их обечаек.

По данным Л. П. Потапова, у западных тувинцев из Хемчика на деревянной рукоятке бубна обычно вырезали рельефные изображения горного козла (те), шкурой которого был обтянут бубен, и всадника верхом на горном козле. В нижней части рукоятки часто вырезали змею. Кожа покрывала только наружную сторону обода, а с другой стороны полость бубна оставалась свободной. Здесь помещались рукоять с перекладиной и подвески (Потапов, 1966: 51).

Е. Д. Прокофьева отмечает, что «в западных районах бубен обтягивали кожей горного козла, в восточных - кожей дикого оленя, а чаще самки марала» (Прокофьева, 1961: 455).

Остов бубна также занимает внимание исследователей. Он состоит исключительно из дерева. Бубны, у которых остов был бы сооружен из другого материала (например, пластик, металл и т. д.), не встречаются. По нашим наблюдениям, в Туве почти повсеместно остов шаманского бубна изготавливают из лиственницы.

По информации Л. П. Потапова, тувинцы-тоджинцы на деревянный остов бубна натягивали кожу лося или марала. У северо-западных тувинцев, как это было установлено нами, бубен обычно обтягивался кожей дикого горного козла. Таким образом, материалы, из которых изготавливалась обечайка шаманского бубна, в разных районах Тувы иногда различались между собой с учетом символики тех животных, к коим шаманы поклонялись, воспринимая их в качестве тотемного животного своего рода.

Необходимо также отметить, что на обечайках у большинства бубнов, хранящихся в музее, имеются большие надрезы. Согласно традиции, после смерти хозяина бубна совершается специальный обряд прекращения звучания бубна.

Что касается гендерных отличий шаманских бубнов, то они не различаются на мужские и женские, в основе своей они все одинаковые.

\section{Заключение}

В результате изучения коллекции бубнов тувинских шаманов можно констатировать следующее. Наблюдения исследователей, сделанные ранее, позволяют составить мнение, что бубны тувинских шаманов четко различаются на западные и восточные. И эта традиция продолжает сохраняться и по настоящее время. Главные различия бубнов шаманов западной и восточной частей Тувы в следующем: используемые шкуры животных; состав деревянного остова бубна; наличие определенной смысловой нагрузки как в символике рукояти, так и в количестве резонаторов на ободе; особенность дополнительных атрибутов во внутренней части бубна.

Сам состав коллекции, ее характеристики, позволяют заключить, что она является одной из наиболее укомплектованных, представляющей практически всю культовую атрибутику тувинских ша- 
манов. Важной особенностью этой коллекции, на наш взгляд, является то, что в силу бытования и функционирования практики шаманизма на территории Тувы в современное время, она продолжает дополняться новыми материалами, в особенности, атрибутикой неошаманов.

Что касается вопросов экспонирования шаманских бубнов с колотушками, то они вместе с другими атрибутами шаманской коллекции представлены в постоянной экспозиции, размещенной в зале № 5 Национального музея. Помимо этого, она периодически выезжает в другие города и регионы России, а также в зарубежные страны, с целью участия в различных выставках. Так, шаманская коллекция тувинского музея с 1997 по 1999 гг. была показана на выставке «Шаманизм тюркоязычных народов Центральной Азии», которая в течение трех лет экспонировалась в таких европейских странах, как Бельгия, Австрия, Германия. По результатам этих экспозиций был издан каталог выставки на английском и немецком языках.

Тем не менее, степень изученности шаманской коллекции на сегодня недостаточна, и в этом направлении исследователям-шамановедам, религиоведам, культурологам и др. предстоит осуществить еще много работы.

\section{СПИСОК ЛИТЕРАТУРЫ}

Алексеев, Н. А. (1980) Ранние формы религии тюркоязычных народов Сибири. Новосибирск : Наука. Сиб. отд-ние. 317 c.

Вайнштейн, С. И. (1961) Тувинцы-тоджинцы: Историко-этнографический очерк. М.: Издательство Восточной Литературы. 218 с.

Грумм-Гржимайло, Г. Е. (1926) Западная Монголия и Урянхайский край. т. 3. Вып. 1. Л.: Типография Главного Ботанического Сада. 414 с.

Дьяконова, В. П. (1977) Религиозные культы тувинцев // Сборник Музея антропологии и этнографии. Памятники культуры народов Сибири и Севера (вторая половина XIX - начало XX в). Т. XXXIII. / отв. ред. И. С. Вдовин Л. : Наука. 232 c. C. $172-216$.

Катанов, Н. Ф. (1893) Письма из Сибири и Восточного Туркестана / Зап. имп. Акад. Наук. СПб.: Записки Императорской Академии наук. Т. XXIII. Т. 53, № 8.114 c.

Кенин-Лопсан, М. Б. (1987) Обрядовая практика и фольклор тувинского шаманства. Конец XIX - начало XX в. Новосибирск.: Наука. 168 с.

Кенин-Лопсан, М. Б. (2009) Тувинские шаманы. М.: ООО ИПЦ «Маска». 325 с.

Кон, Ф. Я. (1934) За пятьдесят лет : Собрание сочинений : в 3 т. М. : [Изд-во Всес. о-ва политкаторжан и ссыльнопоселенцев]. Т. 3: Экспедиция в Сойотию. 293 с.

Прокофьева,Е.Д. (1961) Шаманские бубны// Историко-этнографический атлас Сибири /под общ. ред. М. Г. Левина, Л. П. Потапова. М.: Изд-во Академия наук СССР. 499 с. С. 455.

Потанин, Г. Н. (1883) Очерки Северо-Западной Монголии. Результаты путешествия, исполненного в 1879 г. Материалы этнографические с 26-ю таблицами, рисунками. Вып. IV. СПб. : Типография В. Киршбаума. 1054 с.

Потапов, Л. П. (1966) Очерки этнографии тувинцев бассейна левобережья Хемчика // Труды тувинской комплексной археолого-этнографической экспедиции 1959-1960: Материалы по этнографии и археологии районов бассейна р. Хемчика / отв. ред. Л. П. Потапов. М. ; Л. : Наука. Т. II. 364 с. С. 3-13.

Потапов, Л. П. (1969) Очерки народного быта тувинцев. М.: Наука. 402 с.

Федоров, В. Н. (2005) Тайны вуду и шаманизма. М.: Вече. 480 с.

Чихачев, П. А. (1974) Путешествие в Восточный Алтай. М.: Наука. 360 с.

Яковлев, Е. К. (1900) Этнографический обзор инородческого населения долины Южного Енисея. Минусинск: Тип. В. И. Корнакова. 357 с.

Элиаде, М. (2015) Шаманизм. Архаические техники экстаза. М. : Науч.-изд. центр «Ладомир». 553 с.

Оюн, Д. И. (2006) Древний шаманский бубен вернулся на родину [Электронный ресурс] // ИА «Туваонлайн». 2 мая. URL: https://www.tuvaonline.ru/2006/05/02/buben.html (дата обращения: 21.02.2019).

Chikhachev, P. A. (1845) Voyage scientifique dans l'Altaï oriental et les parties adjacentes de la frontière de Chine: fait par ordre de S. M. l'empereur de Russie. Paris : Gide. 466 p.

Dioszegi, V. (1962) Tuva Shamanism-Intraethnic Differences and Analogies and interethnic Analogies // Acta Ethnographica Academiae Scientiarum Hungaricae. Vol. XI. P. 143-190.

Taube, E. (1981) Notizen zum Shamanismus bei den Tuwinern des Gengelsum // Jahrbuch des Museums fur Volkerkunde zu Leipzig. Band XXXIII. Berlin : Akademie-Verlag. 216 p. P. 43-69.

Дата поступления: 01.03.2019 2. 


\section{REFERENCES}

Alekseev, N. A. (1980) Rannie formy religii tiurkoiazychnykh narodov Sibiri [Early forms of religion among the Turkic-speaking peoples of Siberia]. Novosibirsk, Nauka. Sib. otd-nie. 317 p. (In Russ.).

Vainshtein, S. I. (1961) Tuvintsy-todzhintsy. Istoriko-etnograficheskie ocherki [Tozhu tuvans: historical and ethnographic essays]. Moscow, Nauka. 218 p. (In Russ.).

Grumm-Grzhimailo, G. E. (1926) Zapadnaia Mongoliia i Uriankhaiskii krai. [Western Mongolia and Uryankhai krai]. Vol. 3. Issue 1. Leningrad, Tipografiia Glavnogo Botanicheskogo Sada. 414 p. (In Russ.).

D'iakonova, V. P. (1977) Religioznye kul'ty tuvintsev [Religious cults of Tuvans]. In: Pamiatniki kul'tury narodov Sibiri $i$ Severa (vtoraia polovina XIX - nachalo XX v.) [Monuments of culture of the peoples of Siberia and the North (second half of the 19th - early 20th century)]. Vol. XXXIII / ed. by I. S. Vdovin. Leningrad, Nauka. 232 p. Pp. 172-216. (In Russ.).

Katanov, N. F. (1893) Pis'ma iz Sibiri i Vostochnogo Turkestana [Letters from Siberia and East Turkestan] / Zap. imp. Akad. Nauk. St. Petersburg, Zapiski Imperatorskoi Akademii nauk. Vol. XXIII. Vol. 53, no. 8. 114 p. (In Russ.).

Kenin-Lopsan, M. B. (1987) Obriadovaia praktika i fol'klor tuvinskogo shamanstva. Konets XIX - nachalo XX v [Ritual practice and folklore of Tuvan shamanism in the late 19th - early 20th century]. Novosibirsk, Nauka. 168 p. (In Russ.).

Kenin-Lopsan, M. B. (2009) Tuvinskie shamany [Tuvan shamans]. Moscow, OOO IPTs «Maska». 325 p. (In Russ.).

Kon, F. Ia. (1934) Za piat'desiat let : Sobranie sochinenii [Fifty years : a Collection of essays]: in 3 vol. Moscow, Izd-vo Vses. o-va politkatorzhan i ssyl'no-poselentsev. Vol. 3: Ekspeditsiia v Soiotiiu [An expedition to Soiotia]. 293 p.(In Russ.).

Prokof'eva, E. D. (1961) Shamanskie bubny [Shaman tambourines]. In: Istoriko-etnograficheskii atlas Sibiri [A historical and ethnographic atlas of Siberia]. Ed. by M. G. Levin and L. P. Potapov. Moscow, Izd-vo Akademiia nauk SSSR. 499 p. P. 445. (In Russ.).

Potanin, G. N. (1883) Ocherki Severo-Zapadnoi Mongolii. Rezul'taty puteshestviia, ispolnennogo v 1879 g. Materialy etnograficheskie s 26-iu tablitsami, risunkami. Vyp. IV. [Essays on North-Western Mongolia. Outcomes of the journey completed in 1879. Ethnographic materials with 26 tables and figures. Issue IV]. St. Petersburg, Tipografiia V. Kirshbauma. 1054 p. (In Russ.).

Potapov, L. P. (1966) Ocherki etnografii tuvintsev basseina levoberezh'ia Khemchika [Essays on the ethnography of the Tuvans of the basin of the Khemchik (left bank)]. In: Trudy tuvinskoi kompleksnoi arkheologo-etnograficheskoi ekspeditsii 19591960: materialy po etnografii $i$ arkheologii raionov basseina r. Khemchika [Proceedings of Tuva complex archeological-ethnographic expedition of 1959-1960: Materials on the ethnography and archaeology of the areas in the Khemchik river basin] / Vol. II, ed. by L. P. Potapov. Moscow, Leningrad, Nauka. 364 p. 3-13 pp. (In Russ.). Russ.).

Potapov, L. P. (1969) Ocherki narodnogo byta tuvintsev [Essays on the everyday life of Tuvans]. Moscow, Nauka. 402 p. (In

Fedorov, V. N. (2005) Tainy vudu i shamanizma [Secrets of voodoo and shamanism]. Moscow, Veche. 480 p. (In Russ.).

Chikhachev, P. A. (1974) Puteshestvie v Vostochnyi Altai [A journey to the Eastern Altai]. Moscow, Nauka. 360 p. (In Russ.).

Iakovlev, E. K. (1900) Etnograficheskii obzor inorodcheskogo naseleniia doliny Iuzhnogo Eniseia [An ethnographic review of the non-Russian population of the Southern Yenisei valley]. Minusinsk, Tip. V. I. Kornakova. 357 p. (In Russ.).

Eliade, M. (2015) Shamanizm. Arkhaicheskie tekhniki ekstaza [Shamanism. Archaic Techniques of Ecstasy]. Moscow, Ladomir. 553 p. (In Russ.).

Oyun, D. I. (2006) Drevnii shamanskii buben vernulsia na rodinu [An old shaman tambourine returned to its homeland]. IA Tuvaonlain, 2 May [online] Available at: https://www.tuvaonline.ru/2006/05/02/buben.html (access date: 21.02.2019). (In Russ.).

Chikhachev, P. A. (1845) Voyage scientifique dans l'Altaï oriental et les parties adjacentes de la frontière de Chine: fait par ordre de S. M. l'empereur de Russie. Paris, Gide. 466 p. (In Fr.).

Dioszegi, V. (1962) Tuva Shamanism - Intraethnic Differences and Analogies and interethnic Analogies. Acta Ethnographica Academiae Scientiarum Hungaricae, vol. XI, pp. 143-240. (In Russ.).

Taube, E. (1981) Notizen zum Shamanismus bei den Tuwinern des Gengelsum. In: Jahrbuch des Museums fur Volkerkunde zu Leipzig. Band XXXIII. Berlin, Akademie-Verlag. 216 p. Pp. 43-69. (In Germ.).

Submission date: 01.03.2019. 